\title{
Effect of Planter Speed and Seed Firmers on CORn STAND Establishment
}

\author{
S. A. Staggenborg, R. K. Taylor, L. D. Maddux
}

\begin{abstract}
Proper planter adjustment and operation play an important role in uniform stand establishment for corn. A two-year study was conducted to assess the impact of planter speed and a seed-firming device on corn stand establishment and grain yield. A planter equipped with a vacuum metering system and commercial seed firming devices was used in this study. Corn was seeded in a randomized complete block experiment at three speeds at two locations in Kansas (USA). Plant stand was counted at regular intervals after the first plant emerged to determine emergence rate. Plant spacing within each treatment was measured after complete emergence. Mean plant spacing, standard deviation in spacing, and four spacing indices (miss, multiple, quality of feed, and precision) were calculated to evaluate the plant spacing data. The miss and multiple indices indicate the number of skips and doubles. Planter performance as measured by these indices and standard deviation in plant spacing decreased as planter speed increased. The seed firmer reduced plant spacing standard deviations at a rate equivalent to the standard deviation increase observed when planter speed increased approximately $1.6 \mathrm{~km} / \mathrm{h}$ $(1 \mathrm{mph})$. Corn yield was reduced as planter speed increased at one location, but not the others. This response was the result of lower plant densities at the higher planter speeds, suggesting that one of the goals of the planting process should be to establish adequate plant densities. The seed firmer had no impact on corn yield.
\end{abstract}

Keywords. Corn, Speed, Indices, Yield.

$\mathrm{T}$ he planting operation is one of the most important tasks that corn growers undertake. It should result in a plant stand at the desired density that emerges quickly and uniformly. Plant spacing uniformity and emergence rate are the most common characteristics used by producers to evaluate planter performance. With a trend toward higher corn seeding rates and faster planter speeds, seed singulation devices are being operated at higher speeds. Given typical ground speeds of 6.4 to $9.7 \mathrm{~km} / \mathrm{h}$ (4 to $6 \mathrm{mph}$ ) and seeding rates of 59,000 to 79,000 seeds/ha (24,000 to 32,000 seeds/acre) for northeast Kansas for 76-cm (30-in.) row spacing, this equates to metering 10 to 20 seeds per second. Typical metering systems on row-crop planters singulate 12 to 16 seeds per revolution for finger pickup units and 24 to 30 seed per revolution for vacuum units. As a result of these differences in seed per revolution, it is possible that a vacuum metering system will result in fewer singulation errors compared to a finger pickup metering system at equal seeding rates.

In recent years the farm press has consistently reported yield increases obtained by reducing within row plant spacing variability (Mowitz, 2003; 2002; Finck, 1997).

Article was submitted for review in August 2003; approved for publication by the Power \& Machinery Division of ASAE in April 2004.

Contribution No. 04-035-J Kansas Agricultural Experiment Station, Kansas State University.

The authors are Scott A. Staggenborg, Associate Professor, Department of Agronomy, Randal K. Taylor, ASAE Member Engineer, Professor, Department of Biological and Agricultural Engineering, and Larry D. Maddux, Professor, Department of Agronomy, Kansas State University, Manhattan Kansas. Corresponding author: Scott A. Staggenborg, Kansas State University, 1007 Throckmorton Hall, Manhattan, KS 66506; phone: 785-532-2277; fax: 785-532-5887; e-mail: sstaggen@oznet.ksu.edu.
However, results from university research have been mixed. Krall et al. (1977) reported a significant decrease in yield as within row plant spacing variability, as defined by the standard deviation, increased at two of three sites. Regression results showed a potential decrease of $85 \mathrm{~kg} / \mathrm{ha}$ (3.4 bu/acre) per $\mathrm{cm}$ (in.) of standard deviation in plant spacing.

Vanderlip et al. (1988) found that yield was generally lower as variation in plant spacing increased. However, yield reduction was less than $25 \mathrm{~kg} / \mathrm{ha}$ ( $1 \mathrm{bu} / \mathrm{acre})$ per $\mathrm{cm}$ (in.) of standard deviation. Furthermore, they concluded that within row plant spacing accounted for less than $25 \%$ of the yield variation in all cases. Nielsen (1995) concluded that a yield loss of at least $78 \mathrm{~kg} / \mathrm{ha}(2 \mathrm{bu} / \mathrm{acre})$ per $\mathrm{km} / \mathrm{h}(\mathrm{mph})$ speed increase occurs in the speed range of 6.4 to $11.3 \mathrm{~km} / \mathrm{h} \mathrm{(4} \mathrm{to}$ $7 \mathrm{mph}$ ). This conclusion was based on significantly negative yield response to speed at 5 of 22 sites and he further states that the effects were not widespread. Nielsen (1995) also found that plant spacing variability was significantly affected by speed at 9 of 22 locations. Krall et al. (1977) sampled plant spacing variability in 37 farmer planted fields and found standard deviations ranging from 6.6 to $18.4 \mathrm{~cm} \mathrm{(2.6} \mathrm{to}$ 7.2 in.).

The impact of planter speed on final plant density makes evaluating the impact of variations in plant spacings a difficult task. Vanderlip et al. (1988) produced plant spacing variability while maintaining a constant plant density through hand thinning. Nielsen reported that effects of planter speed might have been confounded by plant density. Staggenborg et al (1999) reported a $2.0-\mathrm{kg} / \mathrm{ha}$ (2.3-bu/acre) increase in corn yields for 2470-plants/ha (1000-plants/acre) increase in plant density for northeast Kansas. Nielsen (1995) also did not account for the influence of multiples or misses on corn yields, whereas Nafziger (1996) reported that multiple plants can increase yields approximately $6 \%$ whereas misses can decrease yields by as much as $7 \%$. These 
results are further complicated by the use of both finger pickup and vacuum planter units (Nielsen, 1995) with no clear indication of either metering device used at a particular location. Planter manufacturers clearly indicate that when operated at speeds above recommended thresholds, the two metering systems respond differently (Anonymous, 1987). Operating instructions for the Max Emerge II (Model 7200, Deere and Co., Moline, Ill.) indicate that when a vacuum metering system is over-speeded, lower than desirable seeding rates will be achieved and if a finger pickup meter is over-speeded, greater than desirable seeding rates will be achieved.

Plant spacing variability is often defined by the standard deviation and as noted above has had mixed results when used to explain yield and plant spacing variability. Though it is easy to calculate and understand, Kachman and Smith (1995) reported it to be a poor descriptor of plant spacing variability. They defined four other indices which they felt better quantified plant spacing variability. Jasa and Dickey (1982) developed a planter index to evaluate plant spacing for various tillage systems. The planter index was an indicator of the average percent difference from the ideal plant spacing and was independent of seeding rate. They reported that even the best planters in their study had $20 \%$ to $30 \%$ error in seed placement and that tillage system had little impact on planter index.

Within row plant spacing variability is potentially caused by two items, metering irregularities and seed bounce in the trench. Panning et al. (2000) evaluated performance of two sugarbeet planters and compared laboratory and field performance. In all situations, they reported that the coefficient of precision decreased with increasing speed. They concluded that laboratory test results could not be used to predict field test results. Their findings would indicate that seed spacing variability could be more related to seed bounce in the trench than metering system irregularities.

Non-uniform plant emergence over time is also a concern of corn growers. Nafziger et al. (1996) reported that uneven corn emergence could reduce yields. However, they suggested that if plants emerged over a period of time less than two weeks, the yield loss was small $(<3 \%)$ and did not justify replanting. To assess corn and soybean stand establishment Erbach (1982) developed the Emergence Rate Index (ERI). The ERI is an indication of how fast and uniform in time the crop emerges from the soil. He reported ERIs ranging from $4.9 \%$ to $11.0 \%$ for corn and $4.9 \%$ to $12.7 \%$ for soybeans.

The objective of this experiment was to evaluate the influence of planter speed (vacuum metering system) and a commercially available seed firming device on corn emergence rate, plant spacing variability, and final grain yields.

\section{Materials AND Methods \\ SITE DESCRIPTION}

A field study was conducted at the Cornbelt Experiment Field in Brown County, Kansas, and at the Paramore Experiment Field in Shawnee County, Kansas. Experiments were conducted in 2001 and 2002 at both locations. All plots were planted with a Max Emerge II row crop planter with a vacuum metering system (Model 7200, Deere \& Co., Moline, Ill.). Long plots were used to ensure that the planter had adequate space to reach the target speeds. At Cornbelt both years, plot lengths were $107 \mathrm{~m}(350 \mathrm{ft})$. At Paramore, the plot length was $457 \mathrm{~m}(1500 \mathrm{ft})$ in length. All plots were planted in $0.76-\mathrm{m}(30-$ in.) rows and were four rows wide for a total plot width of $3.0 \mathrm{~m}(10 \mathrm{ft})$. The soil at the rainfed Cornbelt location was a Grundy clay loam (Fine, smectitic, mesic Aquertic Argiudolls). The soil at the Paramore location was a Eudora silt loam (Coarse-silty, mixed, superactive, mesic Fluventic Hapludolls). Growing season rainfall was supplemented with gravity feed irrigation in the Paramore plots.

Planting information for each site and year are shown in table 1. At Cornbelt two seeding rates, 58,100 and 67,500 seeds/ha $(23,500$ and 27,330 seeds/acre) were used. Corn was planted into undisturbed soybean stubble from the previous year's crop at this location. Planting at the Paramore site consisted of one seeding rate 74,750 seeds/ha $(30,262$ seeds/acre) in a tilled seedbed. The previous crop was soybean. Plots at both sites were fertilized to optimize corn yields based on recommendations from the Kansas State Soil Test laboratory. Weeds were controlled in each plot by herbicides consistent with corn production in the region.

\section{Treatments and Data Collection}

The main treatments included planter speed and commercially available seed firmer (Keaton, Precision Planting, Tremont, Ill.). The seed-firming device is a plastic finger that is attached to the planter seed drop tube and is pulled through the seed furrow while applying a downward force. Three planting speeds were used at each site. The target planting speeds were $6.4,9.7$, and $12.9 \mathrm{~km} / \mathrm{h}(4,6$, and $8 \mathrm{mph})$ at the Cornbelt site in both years and the Paramore site in 2002. Due to miscommunication the target speeds at the Paramore site in 2001 were $8.0,11.3$, and $14.5 \mathrm{~km} / \mathrm{h}(5,7$, and $9 \mathrm{mph})$. Treatments were replicated four times for all site-years except Paramore in 2002 where space limited the study to three replications. Actual planter speed was recorded using a Pocket PC (I PAQ 3670, Hewlett Packard, Palo Alto, Calif.) and a differentially corrected GPS receiver (AgGPS 132, Trimble Corp, Sunnyvale, Calif.) mounted either on the planter or the tractor. Differential correction was obtained from the Coast Guard DGPS beacon tower near Kansas City, Kansas $(305 \mathrm{kHz})$.

To measure the impact of planter speed on plant emergence rate, sub-plots $4.5 \mathrm{~m}(20 \mathrm{ft})$ in length were established in the center two rows of each treatment. After it was determined that the first plant had emerged, the number of emerged plants (visible coleoptiles) were counted in the sub-plots. Stand counts were taken at least four times until emergence was deemed complete. The emerged plants and days after planting were used to calculate an ERI as described by Erbach (1982).

Spacing between plants was measured for 100 consecutive plants in the center two rows of each plot. No visible differences were observed for row units on the planter so each row was considered a single observation for the plot. Plant spacing distribution was characterized using the mean plant

Table 1. Planting information for each site-year.

\begin{tabular}{lccccc}
\hline & \multicolumn{2}{c}{ Cornbelt } & & \multicolumn{2}{c}{ Paramore } \\
\cline { 2 - 3 } \cline { 5 - 6 } & 2001 & 2002 & & 2001 & 2002 \\
\hline Planting date & 19 April & 2 May & & 20 April & 16 April \\
Hybrid & Garst 8342 & Pioneer & & Garst 8342 & Golden Harvest \\
& GLS IT & 33R77 & & GLS IT & H2547 \\
\hline
\end{tabular}


spacing, the standard deviation in plant spacing, and four indices that use theoretical plant spacing based on the expected seeding rate (Kachman and Smith, 1995). These were the miss, multiple, quality of feed, and precision indices. The miss index is an indication of the number of times that the planter produced a skip, while the multiple index is an indication of the number of times that plants were established in close proximity. The quality of feed index is an indication of the number of times that plant spacings are within a range of 0.5 to 1.5 times the theoretical plant spacing. Since quality of feed index is a function of the miss and multiple indices, it will not be illustrated. The precision index is the standard deviation of the plants included in the same range as those used to calculate the quality of feed index.

Grain yields were measured for the entire plot as well as the area where plant spacings were measured. These yields were used to determine the impact of plant spacings on grain yields. Grain yields were determined by harvesting the center two rows of each four-row plot with a plot combine. To determine the impact that the measured plant spacings had on grain yield, the sub-plot areas where plant spacings had been measured were harvested separately and will be the yields reported.

\section{Data Analysis}

Because of differences in planter speeds used, data were not combined across location and analysis of variance was conducted for each location-year. Single degree of freedom contrasts as described by Swallow (1984) were used to test for linear and quadratic response to planter speed. Regression analysis was then used to fit the appropriate models to these responses.

\section{Results AND Discussion EMERGENCE RATE INDEX}

The rate at which the crop germinates and emerges, as measured by the Emergence Rate Index (ERI), varied among the locations and years, but was not influenced by planter speed, seeding rate, or firmer (table 2 and 3). Since the ERI

Table 2. Analysis of variance results for yield, emergence rate index, plant spacing, standard deviation of plant spacing, multiple index, miss index, quality of feed index, and precision index across at Cornbelt in 2002 and Paramore in 2001 and 2002.

\begin{tabular}{|c|c|c|c|c|c|c|c|c|c|c|c|c|c|c|c|}
\hline \multirow[b]{2}{*}{ Source } & \multicolumn{3}{|c|}{$\mathrm{ERI}(\mathrm{cm})$} & \multicolumn{3}{|c|}{$\begin{array}{l}\text { Standard Deviation } \\
(\mathrm{cm})\end{array}$} & \multicolumn{3}{|c|}{ Precision Index $(\mathrm{cm})$} & \multicolumn{3}{|c|}{ Multiple Index (cm) } & \multicolumn{3}{|c|}{ Miss Index (cm) } \\
\hline & $\mathrm{CO} 2^{[\mathrm{a}]}$ & P01 & $\mathrm{P} 02$ & $\mathrm{C} 02$ & P01 & $\mathrm{P} 02$ & $\mathrm{C} 02$ & P01 & $\mathrm{P} 02$ & $\mathrm{C} 02$ & $\mathrm{P} 01$ & $\mathrm{P} 02$ & $\mathrm{P} 02$ & T01 & T02 \\
\hline Firmer & 10.9 & 8.8 & 11.3 & 9.6 & 8.5 & 6.8 & 21.9 & 25.0 & 21.1 & 5.6 & 11.2 & 4.3 & 12.3 & 12.7 & 11.2 \\
\hline No firmer & 10.9 & 8.6 & 11.4 & 10.6 & 9.4 & 7.1 & 20.7 & 25.5 & 21.8 & 4.3 & 10.9 & 5.0 & 12.7 & 14.1 & 10.2 \\
\hline \multirow[t]{2}{*}{$\operatorname{LSD}_{(0.10)}$} & $\mathrm{ns}^{[\mathrm{b}]}$ & $\mathrm{ns}$ & ns & ns & 0.6 & ns & 0.82 & ns & 0.64 & 1.23 & ns & ns & $\mathrm{ns}$ & 1.4 & ns \\
\hline & \multicolumn{15}{|c|}{--------------------------- Prob $>\mathrm{F}----------------------------$} \\
\hline Speed $(S)$ & 0.23 & 0.19 & 0.67 & 0.01 & 0.01 & 0.08 & 0.01 & 0.01 & 0.01 & 0.01 & 0.01 & 0.01 & 0.01 & 0.01 & 0.03 \\
\hline Firmer $(\mathrm{F})$ & 0.97 & 0.14 & 0.39 & 0.18 & 0.03 & 0.38 & 0.02 & 0.69 & 0.10 & 0.08 & 0.76 & 0.51 & 0.82 & 0.10 & 0.40 \\
\hline $\mathrm{S} \times \mathrm{F}$ & 0.78 & 0.84 & 0.60 & 0.29 & 0.39 & 0.81 & 0.22 & 0.09 & 0.21 & 0.22 & 0.65 & 0.80 & 0.64 & 0.12 & 0.69 \\
\hline Speed contrasts & \multicolumn{15}{|c|}{$---------------------------\mathrm{Prob}>\mathrm{F}----------------------------$} \\
\hline Linear & 0.35 & 0.14 & 0.85 & 0.01 & 0.01 & 0.01 & 0.01 & 0.01 & 0.01 & 0.01 & 0.01 & 0.01 & 0.01 & 0.01 & 0.02 \\
\hline Quadratic & 0.17 & 0.96 & 0.40 & 0.42 & 0.36 & 0.89 & 0.13 & 0.43 & 0.73 & 0.02 & 0.92 & 0.19 & 0.88 & 0.79 & 0.83 \\
\hline C.V. $(\%)$ & 4.0 & 2.9 & 3.2 & 17.6 & 10.1 & 11.6 & 5.4 & 4.2 & 3.6 & 34.8 & 21.1 & 44.9 & 29.3 & 15.4 & 20.9 \\
\hline
\end{tabular}

[a] C02 = Cornbelt 2002, P01 = Paramore 2001, P02 = Paramore 2002.

[b] LSD values indicated significance at the 0.10 level.

Table 3. Analysis of variance results for yield, emergence rate index, plant spacing, standard deviation of plant spacing, multiple index, miss index, quality of feed index, and precision index at Cornbelt in 2001. [a]

\begin{tabular}{|c|c|c|c|c|c|c|c|}
\hline & ERI & $\begin{array}{c}\text { Standard } \\
\text { Deviation }(\mathrm{cm})\end{array}$ & $\begin{array}{l}\text { Precision } \\
\text { Index }\end{array}$ & $\begin{array}{l}\text { Multiple } \\
\text { Index }\end{array}$ & $\begin{array}{l}\text { Miss } \\
\text { Index }\end{array}$ & $\begin{array}{c}\text { Mean Plant } \\
\text { Spacing }(\mathrm{cm})\end{array}$ & $\begin{array}{c}\text { Yield } \\
\left(\mathrm{Mg} \mathrm{ha}^{-1}\right)\end{array}$ \\
\hline Firmer & 9.5 & 9.0 & 22.9 & 5.4 & 10.2 & 22.1 & 9.8 \\
\hline No firmer & 9.4 & 10.3 & 22.3 & 4.9 & 14.0 & 23.1 & 9.7 \\
\hline $\operatorname{LSD}_{(0.10)}$ & $\mathrm{ns}^{[\mathrm{b}]}$ & $\mathrm{ns}$ & $\mathrm{ns}$ & $\mathrm{ns}$ & $\mathrm{ns}$ & $\mathrm{ns}$ & $\mathrm{ns}$ \\
\hline 58100 & 9.5 & 10.0 & 22.3 & 4.3 & 10.3 & 24.0 & 9.4 \\
\hline 67500 & 9.4 & 9.3 & 22.9 & 6.0 & 13.8 & 21.2 & 10.0 \\
\hline \multirow[t]{2}{*}{$\operatorname{LSD}_{(0.10)}$} & $\mathrm{ns}$ & $\mathrm{ns}$ & $\mathrm{ns}$ & 0.9 & ns & 0.5 & 0.2 \\
\hline & ----- & ---------- & ------1 & - Prob $>$ F- & ---- & -------- & ------- \\
\hline Seeding rate (SR) & 0.90 & 0.22 & 0.01 & 0.01 & 0.01 & 0.01 & 0.01 \\
\hline Speed (S) & 0.32 & 0.01 & 0.01 & 0.01 & 0.01 & 0.01 & 0.01 \\
\hline Firmer $(\mathrm{F})$ & 0.70 & 0.24 & 0.20 & 0.34 & 0.18 & 0.29 & 0.13 \\
\hline $\mathrm{SR} \times \mathrm{S}$ & 0.58 & 0.97 & 0.84 & 0.99 & 0.49 & 0.84 & 0.19 \\
\hline $\mathrm{S} \times \mathrm{F}$ & 0.16 & 0.44 & 0.23 & 0.26 & 0.40 & 0.24 & 0.95 \\
\hline $\mathrm{SR} \times \mathrm{S} \times \mathrm{F}$ & 0.43 & 0.83 & 0.13 & 0.03 & 0.88 & 0.51 & 0.55 \\
\hline Speed contrasts & ----- & --------- & ------1 & - Prob $>$ F- & ---- & -------- & ------- \\
\hline Linear & 0.26 & 0.01 & 0.01 & 0.01 & 0.01 & 0.19 & 0.04 \\
\hline Quadratic & 0.26 & 0.05 & 0.14 & 0.50 & 0.14 & 0.42 & 0.11 \\
\hline C.V. $(\%)$ & 49 & 13.7 & 5.5 & 19.0 & 21.6 & 2.5 & 2.8 \\
\hline
\end{tabular}

[a] These data are not included in table 2 as seeding rates treatments were also used at this location and year.

[b] LSD values indicated significance at the 0.10 level. 
indicates how fast the crop is emerging, it should be a function of planting conditions and seed/soil contact. Timely rains after planting likely influenced these results. During both growing seasons, soil moisture was adequate at planting or rainfall was received with one week of planting. Under these conditions, the influence of seed firmers or seed placement differences from increased planter speed may be negated compared to seed emergence under more stressful conditions.

\section{STANDARD DEVIATION}

Planter speed and firmers influenced standard deviation of plant spacing (tables 2 and 3 ). Increasing planter speed resulted in greater plant spacing standard deviations at all four location-years (fig 1A). As with ERI, differences exist between the two locations, with standard deviations at Cornbelt increasing at a greater rate than at Paramore. The average rate of change at Cornbelt was $0.5 \mathrm{~cm}(0.3 \mathrm{in})$ or each $\mathrm{km} / \mathrm{h}$ (mph) increase in speed, whereas the rate of change at Paramore was $0.3 \mathrm{~cm}(0.2 \mathrm{in})$ for each $\mathrm{km} / \mathrm{h}(\mathrm{mph})$ increase. As mentioned previously, the differences observed between the two locations are likely the result of soil type differences. It should also be noted that since Paramore is irrigated, a higher seeding rate was selected which will result in lower standard deviations as the average seed and plant spacing is lower.

These results suggest that as planter speed increases, seed metering and placement in the seed furrow may be compromised. Obviously as planter speed increased, seed meter velocity must also increase, potentially reducing the efficiency of the seed metering process. The impact of planter unit vibration on seed metering and placement is also likely to increase as planter speed increases and cause plant spacings to be less uniform, however there was no visible difference in row unit vibration noticed at the different planting speeds. Nielsen (1995) reported increased variation in plant spacings

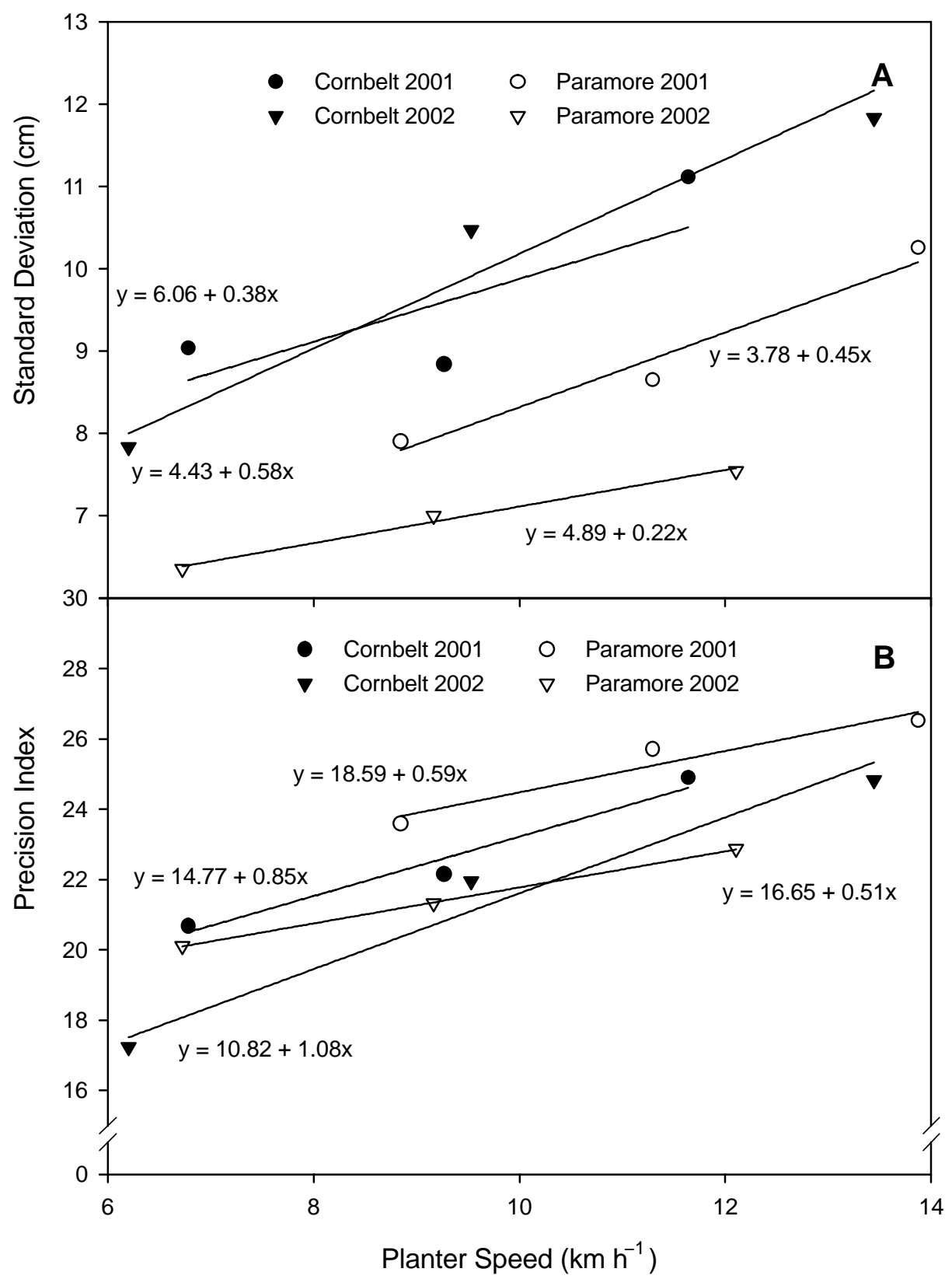

Figure 1. Standard deviation of plant spacings and precision index for three planter speeds across four location-years in northeast Kansas. 
as planter speed increased over a similar range of speeds. The range of standard deviations we measured within the range reported by Doerge et al. (2002) for a well-calibrated seed meter.

Seed firmers reduced plant spacing standard deviations in Paramore in 2001 (tables 2 and 3). This trend was consistent with that observed at the other three location-years where numerically plant spacing standard deviations were lower when seed firmers were used. The reduction in plant spacing standard deviation that resulted from using seed firmers was approximately $0.8 \mathrm{~cm}(0.3 \mathrm{in})$. These results suggest that the seed firmers were likely reducing seed movement in the trench after it left the seed tube.

\section{Precision Index (P)}

Planter speed, seed firmers, and seeding rate all influenced the precision index (tables 2 and 3). Since the precision index is a function of the standard deviation of plant spacing included in the quality of feed index, it should be expected to increase as planter speed increases, as was observed with the standard deviation of all plant spacings. The precision index did increase as planter speed increased, with distinct differences between the two growing seasons (fig. 1B). Unlike the overall standard deviation in which differences occurred between locations regardless of years, the precision index was similar at both locations within each growing season. In 2001, similar responses were measured at both locations with a much greater response than in 2002 .

The impact of seed firmers on the precision index was more consistent than with other indices, with firmers impacting the precision index in two out of the four location-years. However, inconsistencies do exist within these results as seed firmers resulted in a higher precision index at Cornbelt in 2002 compared to the lower values

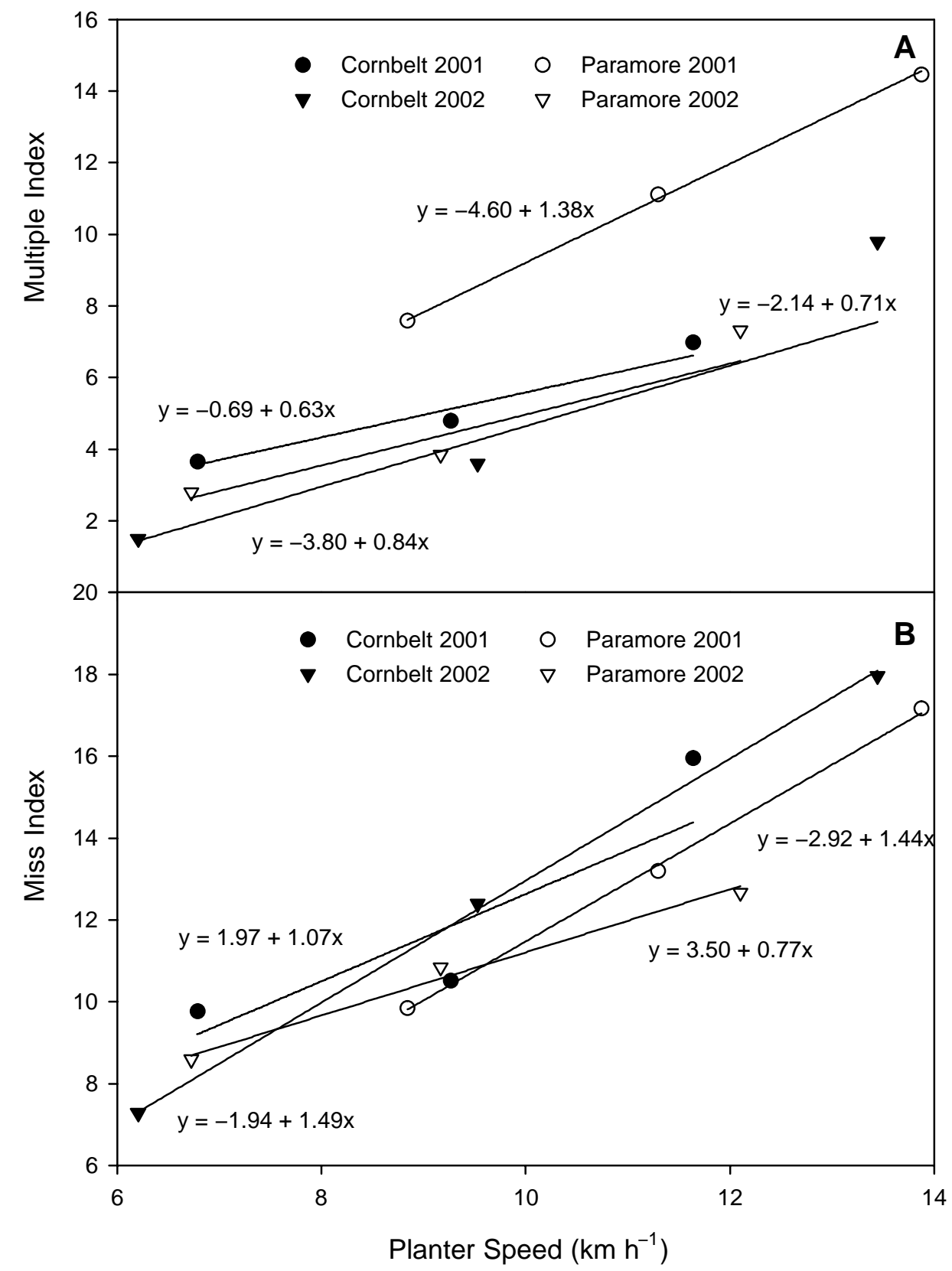

Figure 2. Mulitple index and miss index for three planter speeds across four location-years in Northeast Kansas. 
achieved with firmers at Paramore in 2002. These results indicate that the impact of seed firmers on the precision index is inconsistent.

\section{Multiple AND Miss INDEX}

The number of times that two or more seeds were placed in close proximity (multiples) or the number of times that two seeds were placed at a distance greater than 1.5 the theoretical plant spacing (miss index) was also influenced by planter speed, seeding rate, and seed firmer (tables 2 and 3 ). As with plant spacing standard deviations, as planter speed and seed meter velocity increased, the number of multiples and misses increased (figs. $2 \mathrm{~A}$ and $2 \mathrm{~B}$ ). The rate at which the number of multiples increased as planter speed increased was similar at three of the four location-years. In these three environments, the number of multiples increased at an average rate of 0.7 (1.2) multiples for each $\mathrm{km} / \mathrm{h}(\mathrm{mph})$ increase in planter speed. At Paramore in 2001, the rate of multiples increase was approximately twice the rate observed at the other three location-years. It is possible that this difference was the result of planting conditions that were different than at other locations. The rate at which the miss index increased as planter speed increased was similar for all four location-years. The average rate of increase in the miss index for each $\mathrm{km} / \mathrm{h}(\mathrm{mph})$ increase in planter speed was 1.2 (1.9).

Increasing seeding rates also resulted in an increase in the multiple index at Cornbelt in 2001. As with plant spacing standard deviations, increasing the seed meter velocity was likely to cause seed singulation problems, thus resulting in deviations in seed placement and final plant spacings.

Seed firmer influence on the multiple index was inconsistent throughout this study. At three of the four location-years, the use of firmers had no influence on the multiple index. At Cornbelt in 2002, the multiple index increased when a seed firmer was used. This suggests that the source of multiple plant spacings is the result of the singulation process and not seed bounce, as early results suggest that seed firmers reduced seed bounce. The seed firmer reduced the miss index at Paramore in 2001. The miss indices were numerically less at two of the other three location-years (Cornbelt 2001 and 2002) potentially indicating that the firmer was improving seed-soil contact.

\section{Plant Density}

Plant density, as indicated by the mean plant spacing, was influenced by planter speed, seeding rate, and firmer (tables 3 and 4). As with ERI, plant density response to planter speed appeared to be influenced by soil type, with significant responses only at Cornbelt (fig. 3A). As mentioned previously, the conditions experienced at planting coupled with the heavier soil likely resulted in the differences between the two soil types. The impact that planter speed has on plant density complicates yield evaluations of planter speed studies as plant densities can influence corn yields. Staggenborg et al. (1999) reported an overall response of approximately $94.2 \mathrm{~kg} / \mathrm{ha}$ (1.5 bu/acre) increase in corn yields for every 2470 plants/ha (1000 plants/acre) increase in plant density from 34,600 to 64,250 plants/ha $(14,000$ to 26,000 plants/acre). However, the response was quadratic, meaning that smaller yield increases occurred at the upper end of the range in plant densities. The range of populations experienced in this study ranged from approximately 49,400 to 77,800 plants/ha $(20,000$ to 31,500 plants/acre $)$, with seeding rates ranging from 58,100 to 74,800 seeds/ha $(23,500$ to 30,300 seeds/acre). Nielson (1995) reported that plant density declined at one site and increased at numerous other sites studied. Nafziger (1996) found that if the primary source of plant spacing variability was multiples, it resulted in a higher plant density than the target seeding rate and subsequent established stand.

These results are also consistent with the manufacturer's expectations of this planter unit (vacuum metering system). The operation manual for this metering system states that lower than desirable seeding rates are likely to occur as planter speed increases (Anonymous, 1987). This is in contrast to the expectations of a finger pickup metering system, in which higher than expected seeding rates would occur as planter speed increases. The plant spacing indices also illustrate that at higher speeds, vacuum metering systems may be impacted to a lesser degree than finger pickup metering systems, yet the errors that do occur with a vacuum unit (lower seeding rates) may have a bigger influence on corn yields.

The seed firmer increased plant density (decreased mean plant spacing) at Paramore in 2001. Mean plant spacings were also numerically lower at two of the other three location years (Cornbelt 2001 and 2002). These observations coincide with those of reduced miss indices, furthering the evidence that the firmer improved seed soil contact. We hypothesize that the firmer improved seed-soil contact sufficiently to increase germination of some marginally placed seeds thus reducing plant skips (lower miss index) and increasing plant density (lower mean spacing) at these location-years.

\section{YIELD}

Corn yields were affected by planter speed and seeding rates with both of these responses occurring at Cornbelt in 2001 (tables 3 and 4). At this same location, higher yields were obtained with higher seeding rates, with the 67,500 seeds/ha $(27,330$ seeds/acre $)$ seeding rate producing yields that were approximately $630 \mathrm{~kg} / \mathrm{ha}(10 \mathrm{bu} / \mathrm{acre})$ higher than yields attained at a seeding rate of 58,100 seeds/ha $(23,500$ seeds/acre). This response of $67 \mathrm{~kg}$ (2.6 bu) per 1000 plants is similar to that reported by Staggenborg et al. (1999) at this location.

Table 4. Analysis of variance results for mean plant spacing and yield at Cornbelt in 2002 and Paramore in 2001 and 2002.

\begin{tabular}{|c|c|c|c|c|c|c|}
\hline \multirow[b]{2}{*}{ Source } & \multicolumn{3}{|c|}{$\begin{array}{l}\text { Mean Plant Spacing } \\
(\mathrm{cm})\end{array}$} & \multicolumn{3}{|c|}{$\begin{array}{c}\text { Yield } \\
\left(\mathrm{Mg} \mathrm{ha}^{-1}\right)\end{array}$} \\
\hline & $\mathrm{CO} 2$ & P01 & $\mathrm{P} 02$ & $\mathrm{C} 02$ & P01 & $\mathrm{P} 02$ \\
\hline Firmer & 23.4 & 17.8 & 18.7 & 6.1 & 11.1 & 9.9 \\
\hline No firmer & 23.9 & 18.3 & 18.5 & 6.1 & 11.0 & 9.1 \\
\hline \multirow[t]{2}{*}{$\operatorname{LSD}_{(0.10)}$} & $\mathrm{ns}^{[\mathrm{a}]}$ & 0.4 & ns & ns & ns & ns \\
\hline & \multicolumn{6}{|c|}{$-------------\operatorname{Prob}>\mathrm{F}--------------$} \\
\hline Speed $(\mathrm{S})$ & 0.01 & 0.19 & 0.12 & 0.72 & 0.19 & 0.93 \\
\hline Firmer $(\mathrm{F})$ & 0.24 & 0.08 & 0.28 & 0.93 & 0.67 & 0.24 \\
\hline $\mathrm{S} \times \mathrm{F}$ & 0.48 & 0.44 & 0.84 & 0.51 & 0.99 & 0.25 \\
\hline \multicolumn{7}{|c|}{ Speed Contrasts ------------- Prob $>\mathrm{F}-------------$} \\
\hline Linear & 0.03 & 0.13 & 0.02 & 0.66 & 0.29 & 0.90 \\
\hline Quadratic & 0.37 & 0.39 & 0.73 & 0.44 & 0.10 & 0.84 \\
\hline C.V. $(\%)$ & 3.9 & 3.4 & 2.3 & 15.6 & 7.0 & 15.3 \\
\hline
\end{tabular}

[a] LSD values indicated significance at the 0.10 level. 


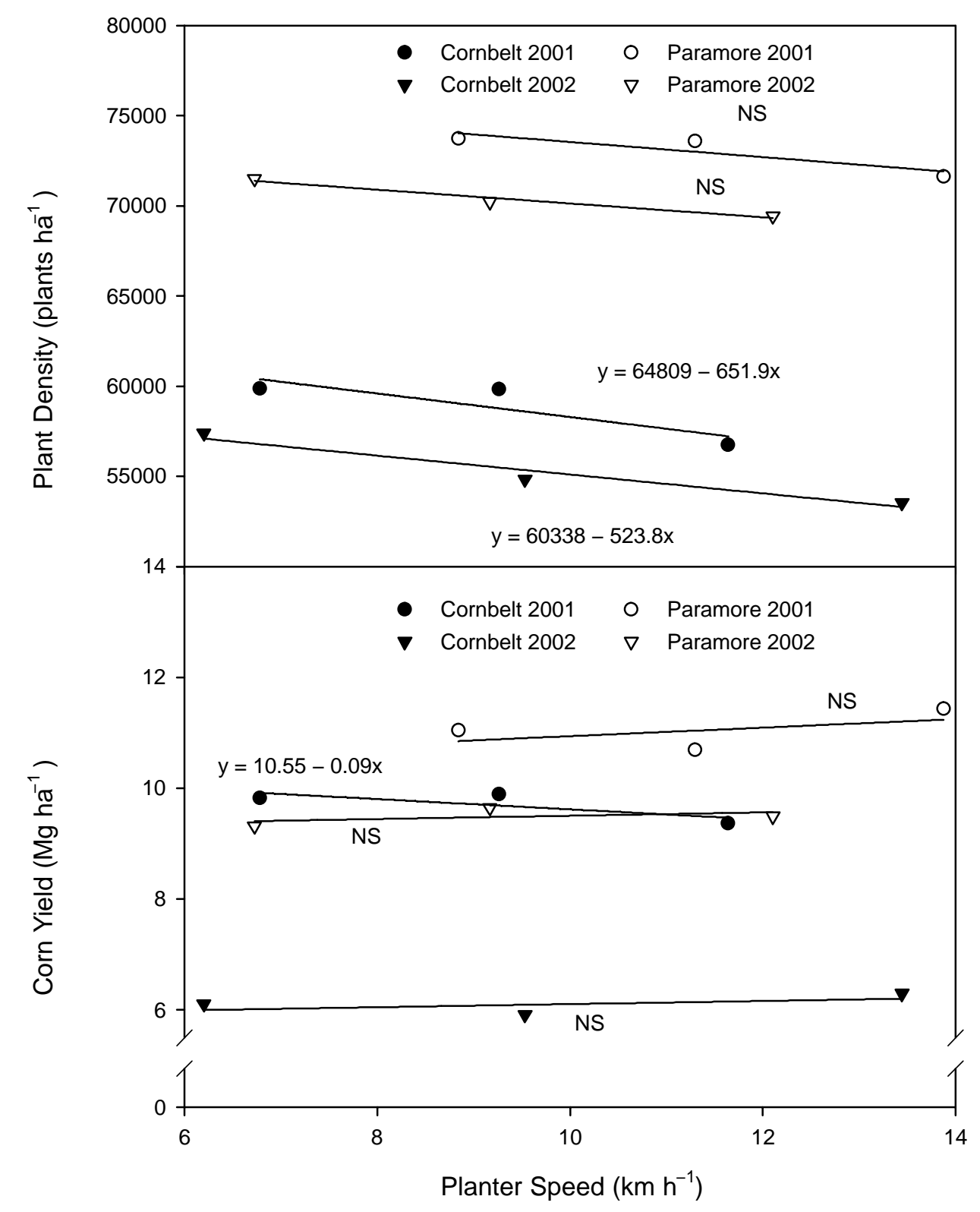

Figure 3. Plant density and corn yields for three planter speeds across four location-years in northeast Kansas.

Corn yields declined as planter speed increased at Cornbelt in 2001 (fig. 3B). Yields decreased at a rate of $93.7 \mathrm{~kg} / \mathrm{ha}(2.4 \mathrm{bu} / \mathrm{acre})$ per $\mathrm{km} / \mathrm{h}(\mathrm{mph})$ as planter speed increased from approximately $7.2 \mathrm{~km} / \mathrm{h}(4.5 \mathrm{mph})$ to over $11.3 \mathrm{~km} / \mathrm{h}(7 \mathrm{mph})$. Planter speed and seeding rates affected yields through the impact that each had on plant density at Cornbelt in 2001. It is obvious that increasing seeding rate will result in increased plant densities, which has already been shown to increase yields within the plant densities established in this study (Staggenborg et al., 1999). The less obvious impact on final plant density is that of planter speed. As planter speed increased, the number of multiple and misses increased as did the overall standard deviation and precision index. This strongly supports that seed meter performance declines as planter speed, thus metering speed, increases. However, these indices were not strongly correlated to corn yields (table 5). Of these indices (multiple, miss, and standard deviation), multiples had the highest correlation coefficient followed by standard deviation. The miss index had the lowest correlation to yield. Nafziger (1996) reported that misses reduced yields as a result of reducing plant populations. He also reported that when misses increased standard deviation yield loss per $\mathrm{cm}$ (in.) of standard deviation ranged from 61.8 to $183 \mathrm{~kg} / \mathrm{ha}$ per $\mathrm{cm}(2.3$ to 7.4 bu/acre per in.). Krall (1977) and Nielsen (1995) reported 
Table 5. Correlation coefficients for six plant spacing variables with corn yields. Analysis includes four location years.

\begin{tabular}{ccccc}
\hline $\begin{array}{c}\text { Plant Spacing } \\
(\mathrm{r})\end{array}$ & $\begin{array}{c}\text { Standard } \\
\text { Deviation (r) }\end{array}$ & $\begin{array}{c}\text { Multiple } \\
\text { Index (r) }\end{array}$ & $\begin{array}{c}\text { Miss Index } \\
(\mathrm{r})\end{array}$ & $\begin{array}{c}\text { Precision } \\
\text { Index (r) }\end{array}$ \\
\hline$-0.64^{[\mathrm{a}]}$ & $-0.23^{[\mathrm{b}]}$ & $0.39^{[\mathrm{a}]}$ & 0.04 & $0.64^{[\mathrm{a}]}$ \\
\hline
\end{tabular}

[a] Represents significance at the 0.01 level.

[b] Represents significance at the 0.05 level.

similar losses per $\mathrm{cm}$ increase in standard deviation. However, Nafziger (1996) reported that when standard deviation of plant spacings increased because of multiple plants, yield response was positive and at rates much higher than reported for the misses. He attributed increases in corn yield from doubles to the impact that the multiples had on final plant density. Although the individual plants that made up the multiple produced less grain per ear, the two together produce $81 \%$ more grain than a single plant. This is reflected in our data with the positive correlation between multiple index and yield and the low and very low correlations between standard deviation and miss indices and yield.

\section{Conclusions}

Our results indicate that although increasing planter speed reduces seed meter performance, the primary detriment to higher planter speeds is the risk of reducing stand establishment and final plant stands. This is supported in this study by a correlation coefficient of 0.64 for plant density and corn yield. This suggests that the focus of planter performance in the field should be toward establishing the correct seeding rate and subsequent plant stands and less on absolute plant spacing. These results also indicate that seed firmers reduce seed bounce in the trench as indicated by lower standard deviations and are potentially improving seed-soil contact as indicated by lower miss indices and greater plant densities.

\section{REFERENCES}

Anonymous. 1987. Operators Manual: Model 7200 MaxEmerge 2 Drawn Planter. John Deere Harvester Works. Moline, Ill.: Deere \& Co.

Doerge, T., T. Hall, and D. Gardner. 2002. New research confirms benefits of improved plant spacing in corn. Crop Insights 12(2): $1-5$.

Erbach, D. C. 1982. Tillage for continuous corn and corn-soybean rotation. Transactions of the ASAE 25(4): 906-911, 918.

Finck, C. 1997. Keep the planter pass sacred. Farm Journal 121(7): 16-18.

Jasa, P. J., and E. C. Dickey. 1982. Tillage factors affecting corn plant spacing. Transactions of the ASAE 25(6): 1516-1519.

Kachman, S. D., and J. A. Smith. 1995. Alternative measures of accuracy in plant spacing for planters using single seed metering. Transactions of the ASAE 38(2): 379-387.

Krall, J. M., H. A. Esechie, R. J. Raney, S. Clark, G. TenEyck, M. Lundquist, N. E. Humburg, L. S. Axthelm, A. D. Dayton, and R. L. Vanderlip. 1977. Influence of within-row variability in plant spacing on corn grain yield. Agron. J. 69 (5): 797-799.

Mowitz, D. 2002. Precision planting. Successful Farming 100(5): 26-28.

Mowitz, D. 2003. Precision planting pays off. Successful Farming 101(1): 33-42.

Nafziger, E. D. 1996. Effects of missing and two-plant hills on corn grain yield. J. Prod. Agric. 9(2): 238-240.

Nielsen, R. L. 1995. Planting speed effects on stand establishment and grain yield of corn. J. Prod. Agric. 8 (3): 391-393.

Panning, J .W., M. F. Kocher, J. A. Smith, and S. D. Kachman. 2000. Laboratory and field testing of seed spacing uniformity for sugarbeet planters. Applied Engineering in Agriculture 16(1): 7-13.

Staggenborg, S.A., D.L. Fjell, D.L. Devlin, W.B. Gordon, L.D. Maddux, and B.H. Marsh. 1999. Selecting optimum planting dates and plant populations for dryland corn in Kansas. J. Prod. Agric. 12: 85-90.

Swallow, W. H. 1984. Those overworked and often misused mean separation procedures - Duncan's, LSD, etc. Plant. Dis. 68: 919-921.

Vanderlip, R. L., J. C. Okonkwo, and J. A. Schaffer. 1988. Corn response to precision of within-row plant spacing. Applied Agric. Res. 3: 116-119. 